\title{
The Relationship between Association and Moral Development of Student Learning Activities
}

\author{
Nur Sakinah \\ Universitas Muhammadiyah Sumatera Utara, Medan, Indonesia \\ Sakinahn077@gmail.com
}

\begin{abstract}
One indicator of decreased student learning activities is student association. In addition, there is a tendency for students' moral development to be unfavorable. Both of these indicators have a significant relationship to the tendency of student learning activities. Therefore, improvements and improvements to social interaction and moral development will have a positive impact on increasing student learning activities. This study aims to see and examine the extent to which the relationship between association and moral development of student learning activities in Madrasah Aliyah Muhammadiyah Mandala Medan.
\end{abstract}

Keywords

association; moral

development

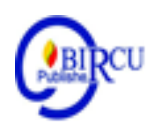

\section{Introduction}

National development is essentially the development of Indonesian people as a whole. To realize this, the government seeks to prepare qualified young generation with the basic concept of active and holistic child growth and development, which includes aspects of education, health and nutrition services directed at efforts to realize improvements or progress in children's survival. The early phase is a golden age for child development, because in this phase it is very crucial for the child's development until he enters adulthood.

Aspects of child development that must be developed according to $\mathrm{Jalal}^{1}$ include aspects of moral development and religious values, physical aspects, language aspects, cognitive aspects and social emotional aspects as well as art. Moral growth and development and relationships can be anticipated since children enter secondary education. However, if children have reached puberty or adolescents, their education and control must be increasingly improved, because at this time children are very vulnerable to all kinds of relationships that are not in accordance with the religious and moral values of society.

The environment in which the child will live and mingle has a very big role in shaping the soul of the child's personality. A good environment will encourage children to carry out activities in developing all their talents and potential. Environment that is not good will affect its development so that the talent and good potential it has will experience obstacles in its development.

Education obtained in schools is directed towards achieving maturity. Maturity can be described in the knowledge, understanding, skills, attitudes and values that students must have after completing their education. ${ }^{2}$

However, due to wrong guidance and wrong association, it can interfere with educational goals, both at home and at the madrasa. In fact, at this time, it has often been found in the mass media about the incidents of children who mistreat their parents and

\footnotetext{
${ }^{1}$ Fasli Jalal, Stimulasi Otak untuk Mengoptimalisasi Kecerdasan Anak, Buletin PAUD, Jurnal Ilmiah Anak Usia Dini, Cetakan Pertama, Edisi 02 (Jakarta: Direktorat PADU, 2002), p. 12.

${ }^{2}$ W.S Winkel, Psikologi Pengajaran,Cetakan Kedua (Jakarta: Gramedia Widya Sarana Indonesia, 1989), p. 21.
} 
teachers. This event is one of the influences of the times that has changed the values among students.

Reduced appreciation from the teacher and the depletion of the need for religious values will keep children from moral values that should be owned. The teacher never asks to be appreciated, but it is indeed an obligation for students to respect and appreciate it because of their services and dedication in educating students. Because their services and sacrifices are created by an intelligent, capable, and with their services a smart, successful and advanced person will be created.

Decreased moral and ethical values among many students are a contributing factor. What is obtained at the madrasa cannot be matched with what is found in the community, so he is confused about the safe direction he must go through. Besides, it is also due to the lack of parents' attention to children, so whatever children do outside the home, parents do not know the consequences of their busy lives.

The magnitude of the influence of this association can also affect students' mental development. If students are able to control relationships and assess positive things to emulate, then the moral development of students will avoid moral depravity, but if students lead to negative developments, then student morals will also lead to negative ones. These associations greatly influence student learning activities.

When viewed from student learning activities, association is one of the factors that can influence student learning. The influences of students associating friends more quickly enter the soul than expected. Good associates will have a good effect on students, and vice versa bad associates will also affect bad traits as well. In order for students to learn well, it is necessary to make efforts for students to have good associates and the coaching and supervision of parents in education must be wise enough. ${ }^{3}$

\section{Review of Literature}

In the process of teaching and learning students are the target of providing assistance by the teacher. Because the purpose and educational interaction is to guide and assist students in behavior change. Changes that occur during lessons, often cause a change because of the ideals of life. In addition, the learning process can also strengthen the direction of student ideals. The process can quickly help students progress toward the expected goals. Therefore, students must have a good attitude and a strong mentality, be serious in learning, so that if this is realized by students, students will have responsibility towards themselves and try to seek knowledge as optimal as possible.

Student learning activities, both in the classroom and outside the classroom are in principle a means of self-development, learning activities can be started by learning to understand and memorize various kinds of lessons, as explained by al-Abrasyi ${ }^{4}$, that studying first is intention, then listening, then understand it, after that memorize it, then practice it and then spread it. That is, that the first human intends to learn then listen and be attentive to what is described, then memorize it and disseminate opinions and ideas among humans.

\footnotetext{
${ }^{3}$ Slameto, Belajar dan Faktor-Faktor yang Mempengaruhinya, Cetakan Ketiga (Jakarta: PT. Rineka Cipta, 1991), p. 71.

${ }^{4}$ M. Athiyah al-Abrasyi, Dasar-Dasar Pendidikan Islam, Cetakan Pertama (Jakarta:Bumi Aksara, 1970), pp. 135136.
} 
In line with the above view, in the process of teaching and learning students are given the freedom to act and act on the basis of their own creativity, learning while doing is a goal in the education process. However, if the students themselves do not concentrate on their lessons and are lazy and consider trivial, then the learning process will not run smoothly, also if students do not have good morals will affect the learning process. Learning is said to be productive if students can use their knowledge to get new ideas, solve problems, plan activities, and conduct experiments. ${ }^{5}$

Delivering learning material means carrying out a number of activities, but the activity will be of no use if it does not lead to a specific goal. This means that a teacher must have a purpose in teaching activities, therefore every teacher wants every teaching to be received as clearly as possible by the students. To understand a thing in a person, a process occurs called the learning process through teaching models that fit the needs of the learning process. Through teaching models, the teacher has the task of stimulating and improving the course of the learning process. To be able to carry out the task properly, the teacher must have the ability and know how the model and the learning process take place.

The learning model and process will explain the meaning of the activities carried out by the educator during the learning process. Every instructor or educator will explain the reasons why he conducts activities in learning by determining certain attitudes. Stating that when teachers do not know what is really going on in the minds of students to understand something, presumably he will not be able to give the right encouragement to those who are learning. Students will easily forget the lessons they have received, if the instructor does not give a correct and pleasant explanation.

One of the ability of teachers to manage learning is the creation of conducive learning and learning processes, as well as information processing. The process occurs through mental processes that are individually directed to achieve the expected goals. If learning is individual, learning outcomes are also individual. ${ }^{6}$ That is, even though in a teaching a teacher gives the same information to students, each student will obtain different results. The difference in results depends entirely on how the relevant student processes or processes the information in general, including the process of collecting and selecting information through the senses, compiling or organizing the information that has been selected into memory and using the information stored in memory to do something. ${ }^{7}$

The moral problem is a problem that is thought for the community, both developed and backward society. Because moral damage can interfere with the peace of others. If in a community, many of its citizens have been morally damaged, then the state of the community will be shaken. Thus, what is meant by morals in terms of some of the definitions will be described.

Character is also called personality, as explained by James Draver, namely: Personality is used in various senses, both popularly and psychologically. The most comprehensive and satisfactory being the integrated and dynamic organization of the physical, mental, moral, and social qualities of the individual, as the manifest it self to other people, in the give and take of social life. ${ }^{8}$ (personality is included in many meanings, both popular and psychological, the

\footnotetext{
${ }^{5}$ Ibid., p. 136.

${ }^{6}$ AndulMu'ti, Proses Belajar: Pendekatan Kognitif, dalam PBM-PAI di Sekolah: Eksistensi dan Proses Belajar Mengajar Pendidikan Agama Islam, Semarang: Fakultas Tarbiyah IAIN Wali Songo Semarang, 1998, p. 96.

${ }^{7}$ Ulrich Neisser, Cognition nd Reality, Cetakan Pertama, San Fransisco: W.H. Freeman, 1976, p.1.

${ }^{8}$ James Draver, The Pinguin Dictionary of Psychology, Cetakan Kedua, (Aucland New Zeland: Penguin Book, 1981), p. 208
} 
most encompassing and satisfying is (which defines as) an integrated and dynamic organization (set) between the physical, mental, moral and social values of someone as a manifestation of themselves towards others reciprocally in people's lives).

Personality includes the overall quality of a person. The quality will appear in ways of doing, ways of thinking, ways of expressing opinions, attitudes, interests, philosophy of life and beliefs. ${ }^{9}$

Based on the above quote, it can be concluded that the characteristics of students can be changed by intensive and planned education, both in learning planning and syllabus. In the teaching and learning process, an educator must understand as much as possible the nature of his students as subjects and objects of education. Some things that need to be understood regarding the characteristics of students according to Suwarno ${ }^{10}$, are:

First, students are not miniature adults, they have their own world, so teaching and learning methods should not be compared to adults. Adults should not exploit the world of students, by obeying all the rules and desires, so that students lose their world. Students who lose their world, then make a void of life in the future.

Second, students have needs and demand to fulfill those needs as much as possible. Individual needs, according to Abraham Maslow,

'There are five hierarchies of needs grouped into two categories, namely: (1) basic tariff needs which include physical needs, security and security, love and belonging (social), and self-esteem, (2) meta needs meta needs, including what is contained in self-actualization, such as justice, goodness, beauty, order, unity and so on."11

Third, students have differences between individuals and other individuals, both differences caused by endogenous factors, and exogenous (environment) which include physical, intelligence, social, talent, interests, and environmental factors that influence it.

Fourth, students are seen as a unity of the human system. In accordance with the nature of human beings, such as students as monopluralists, students' personalities even though it consists of many aspects, is a unity of body and soul (copyright, taste, and intention).

Fifth, students are subjects and objects at the same time in education that are possible to be active, creative, and productive. Each student has their own activities (self-help) and their own creativity (creativity), so that in education do not view children as passive objects that usually only receive, listen alone.

Sixth, students follow certain development periods and have a pattern of development and tempo and rhythm. The implication in education is how the education process can be adjusted to the pattern and tempo, as well as the rhythm of the development of the students. The level of ability of students is largely determined by age or period of development, because that age can determine the level of knowledge, intellectual, emotion, talent, interests of students, both viewed from the biological, psychological and didactic dimensions.

The formation of student characters in teaching and learning activities requires preparation and patience as well as continuous follow-up, because the character of students has its own characteristics. Each individual has differences, while on the educational side of their students must lead to definite changes, this is where a more comprehensive approach is

\footnotetext{
${ }^{9}$ Ahmad D. Marimba, Pengantar Filsafat Pendidikan Islam, Cetakan Keempat, (Bandung: al-Ma'arif, 1986), p. 67.

${ }^{10}$ Suwarno, Pengantar Ilmu Pendidikan, Cetakan Ketiga, (Jakarta: Aksara Baru, 1982), p. 85.

${ }^{11}$ Abraham H. Maslow, Motivation and Personality, (New York: Harper and Row Publishing,, 1970), pp. 37-47.
} 
needed. Therefore, education must know what factors can influence the formation of student character, among these factors are:
a. Physical factors
b. Reason factor
c. Religious factors
d. Moral Factor
e. Spiritual Factors (psychiatric)
f. Art factor (beauty)
g. Social Factors. ${ }^{12}$

All of the above factors are believed to be a driving force for students to develop their character. Because humans or students easily change when what they hear and see can attract their hearts. According to Widodo Supriono ${ }^{13}$, humans are multidimensional creatures that are different from other creatures. Broadly speaking, he divides humans into two dimensions, namely the physical and spiritual dimensions. Spiritually, humans have unlimited spiritual potential. These potentials appear in the form of understanding something (ulil al bab), being able to think / reflect, use reason, be faithful, be pious, remember or take lessons, listen to the truth of the word of God, be knowledgeable, be knowledgeable, be able to master appropriate and final technology humans born into the world have brought nature. Humans are essentially social beings. Since humans are born into the world, they always need others to fulfill their needs. After growing up, humans cannot be separated from their relationships with other people and their communities. In establishing social relations, there needs to be adjustment, and with a good adjustment someone can be accepted into a group in order to achieve his life goals.

In meeting the needs of human life, each individual is socially assisted by others, for these needs humans must relate in their relationships with others, including children who are still studying at Senior High School Level. There are several reasons that cause children to leave the house and get along with others such as: lack of learning facilities, eliminating boredom and the demands of community life. ${ }^{14}$

Facilities are one of the factors that support in achieving goals in teaching and learning. Students who lack learning facilities cause it to look outside and socialize outside the home. Because learning facilities are not met, students try to get it from other people, then one way is to borrow it from others and do not demand association. ${ }^{15}$

In relations between people, both in the village, especially in international forums, namely the association between nations is always needed ethics or more appropriate ethics (good manners) of association. It seems that this is human nature that humans have a sense of wanting to be respected by others and at the same time wanting to respect others. So the famous phrase in everyday life among us is "if you want to be appreciated by others, then respect others" From this sense of respect for others, someone tries to behave and behave politely. The point is how we behave and behave politely to others.

\footnotetext{
${ }^{12}$ Rayamulis, Ilmu Pendidikan Islam, Cetakan Ketiga, p. 120.

${ }^{13}$ Widodo Supriono, Filsafat Manusia dalam Islam, Reformasi Filsafat Pendidikan Islam, Cetakan Kelima, (Pustaka Pelajar, Jogyakarta, 1996), p. 179.

${ }^{14}$ W.A Gerungan, Psikologi Sosial, dicetak Oleh Rosda Offset, (Bandung: Erasco, 1991), p. 312.

${ }^{15}$ Ibid., p. 137.
} 


\section{Research Method}

This research is a survey method with correlational techniques, in accordance with the opinion of Donald Ary et al., ${ }^{16}$ They say that the survey can be used to investigate relationships or to test hypotheses. Correlation technique is used to measure the degree of relationship between association (X1) and moral development (X2) with student learning activities (Y) both individually and together. This research deals with the relationship between various variables, testing hypotheses and developing generalizations, principles or theories that have universal validity.

The variables in this study consisted of Intercourse (X1), Moral Development (X2), and Student Learning Activity variable (Y). Based on the theoretical study discussed in Chapter II, conceptually and operationally the research variables can be explained as follows:

\subsection{Student Learning Activity Variables}

a. Conceptual Definition

Student learning activities are student learning activities, both that occur in class and at home. Student learning activities in the classroom are controlled by the teacher, while at home are controlled and controlled by the students' parents.

b. Definition of Variable Operations

Student learning activities are the scores obtained by respondents after answering student learning activity instruments that contain the level of seriousness of student learning. Student learning activities are measured by indicators, 1) class activities, 2) activities outside the classroom, 3) activities at home, 4) activities outside the home, and 5) activities in the learning club.

c. Instrument Validation

The validation of student learning activities is calculated using the Product Moment formula, Azwar also said that if the item score is not a dichotomy, but is interval-scale, then the product moment correlation technique can be used. The results of the validity calculation are compared with the price table of product moment criticism. The instrument is planned to distribute as many as 25 questions. Furthermore, to see the reliability of student learning activities sought by using the Cronbach alpha formula.

\section{Discussion}

Association is a means for students to realize their existence with others. Every student needs someone else to help him get to know and learn about his environment. Therefore, association can be used as a place for students to train themselves to understand others and can also be used as a tool to form personality patterns.

Learning activities do not happen by themselves, but because there are influences or stimuli from outside him that gives impetus to find out. Besides that, a strong curiosity in students can also be a trigger or a motivating factor for students to carry out learning activities. Daily association is believed to have a close relationship with the desire of students to carry out learning activities. Therefore, the better the pattern of interaction that is built, the

\footnotetext{
${ }^{16}$ Donald Ary, Lucy R. Jacobs dan Asghar Bazavieh, Introduction to Research in education, Cetakan Pertama, (New York: Holt, reinhart and Winston, 1970), p. 301.
} 
better the learning activities in students. A good association will bring a good impact on student learning activities.

The moral development of a student always occurs as long as he has a good enough relationship. Moral development is closely related to the intensity of student activities both at school and the environment in which they live. Because morals are part of the reflection of society which is used as a guide for carrying out activities, it is also used as a guide in determining the good and bad of a behavior or deed. Measures of good and bad in society are always measured by morals, both morals derived from religious teachings (morals) and morals derived from values that develop in society.

Student learning activities both at school and in the community can not be separated from the moral influence that develops in their respective environments. Therefore, moral development is believed to have a very close relationship with student learning activities. The better moral development, the better the learning activities undertaken by students.

Based on previous information, that good relationships have a good impact or influence on student learning activities. Likewise with moral development has a fairly close relationship with the development of student learning activities both at school and in the neighborhood. Each variable is believed to have a very close relationship to the next variable. This means that association and moral development are believed to have a very close relationship with student learning activities. The better social interaction and development of students, the better the learning activities. Therefore, association and moral development together have a very close relationship with student learning activities.

\section{Conclusion}

Every education must realize that each phase of development will bring new changes to the child, both physically and spiritually. There are several things parents need to know according to the child's development, namely:

1. Every phase experienced by children is a transition or a period of preparation for the next period.

2. The development experienced by children is physical and spiritual development. Therefore, in an effort to help the development of children, parents and teachers are expected to pay attention to this development and always exercise control and consideration so that neglect does not occur in the child.

3. It is in the family that the child develops, therefore the family occupies an important place for the formation of the person as a whole child who will be taken throughout his life. The family builds character, gives religious sense, cultivates traits, habits, hobbies, ideals and so on, as well as other institutions in the community to help, continue, increase and deepen what is obtained from the family.

The family is the first environment that provides education that affects the development of students. In the family the child will get a good opportunity to obtain the religious moral values he receives from parents. The role of leadership and role models of parents can shape the personality of children, while social interaction can function positively and negatively on children's moral development.

\section{References}

Ary, Donald, Lucy R. Jacobs dan Asghar Bazavieh, Introduction to Research in Education, New York:Holt, Reinhart and Winston, 1970 
Azhar, Saifuddin, Realibilitas dan Validitas, yogyakarta:Pustaka Pelajar, 1995.

Antony J. Nitko, Educational Test and Measurement an Introduction, New York:Harcourt Brave Javanovich, Inc., 1983.

Ahmad D. Marimba, Pengantar Filsafat Pendidikan Islam, Bandung:al-Ma'arif, 1986.

Cronlund, Norman E., Meusurument and Evaluation in teaching, New York: MacMillan Publishing Company, 1985.

M. Athiyah al-Abrasyn, Dasar-Dasar Pendidikan Islam, Jakarta: Bumi Aksara, 1970.

Fasli Jalal, Stimulasi Otak untuk Mengoptimalisasi Kecerdasan Anak, Buletin PAUD, Jurnal Ilmiah Anak Usia Dini, Edisi 02, Jakarta:Direktorat PAUD, 2002.

Gerungan, W.A, Psikologi Sosial, Bandung:Erasco, 1991.

Hurlock, Elizabeth, Psikologi Perkembangan:Suatu Pendidikan Sepanjang Rentang Kehidupan, terj. Istiwidayanti, Jakarta:Erlambang, 1991.

Humadi, Tatap Angarsa, Akhlak yang Mulia, Surabaya:Bina Ilmu, 1991.

James Draver, The Pinguin Dictionary of Psychology, Aucland New Zeland: Penguin Book, 1981.

Mu'ti, Abdul, Proses Belajar: Pendekatan Kognitif, dalam PBM-PAI di Sekolah:Eksistensi dan Proses Belajar Mengajar Pendidikan Agama Islam, Semarang:Fakultas Tarbiyah IAIN Wali Songo Semarang, 1998.

Maslow, Abraham. H, Motivation and Personality, New York:Harper and Row Publishing, 1970

Rayamulis, Ilmu Pendidikan Islam, Jakarta:Kalam Mulia, 2004.

Suyanto, Agus, Psikologi Perkembangan, Jakarta: Aksara Baru, 1999.

Slameto, Belajar dan Faktor-Faktor yang Mempengaruhinya, Jakarta: PT. Rineka Cipta, 1991.

Suwarno, Pengantar Ilmu Pendidikan, Jakarta:Aksara Baru, 1982.

Supraktiknya, A., dalam kata Pengantar, Hall, Calvin, and Gardner Lindsey, Teori-Teori Psikodinamik (klinis), terj. Yustinus, judul asli, Theories of Personality, Yogyakarta:Kanisius, 1993.

Supriono, Widodo, Filsafat Manusia dalam Islam, Reformasi Filsafat Pendidikan Islam, Pustaka Pelajar, Jogyakarta, 1996.

Ulrich Neisser, Cognition nd Reality, San Fransisco: W.H. Freeman, 1976.

Winkel, WS., Psikologi Pengajaran, Jakarta:Gramedia Widya Sarana Indonesia, 1989. 